Sains Malaysiana 49(7)(2020): 1729-1743

http://dx.doi.org/10.17576/jsm-2020-4907-23

\title{
Syngas Production from Rubberwood Biomass in Downdraft Gasifier Combined with Wet Scrubbing: Investigation of Tar and Solid Residue
}

(Pengeluaran Singas daripada Biojisim Kayu Getah dalam Sistem Pengegas Alir Turun Digabungkan dengan Penggahar Basah: Kajian Tar dan Sisa Pepejal)

\author{
Syed Haseeb Sultan, Arkom Palamanit*, Kua-anan Techato, Muhammad Amin, \\ KHURSHID AHMED \& ASADULLAH
}

\begin{abstract}
Production of synthesis gas by gasification is still a challenge due to the tar in the synthesis gas (syngas). This tar needs to be eliminated by appropriate methods before using the syngas as a fuel. Moreover, the solid residue after gasification also needs to be properly managed or destroyed. Therefore, the aim of this study was to investigate tar and solid residue generated by gasification of rubberwood biomass, including rubberwood chips (RWC), rubberwood pellets (RWP), rubberwood unburned char (UBC), and their blends, in a downdraft gasifier. Waste vegetable oil (WVO) and water were used as scrubbing media. Properties of the biomass samples were characterized by proximate and ultimate analysis, as well as for the higher heating value. The downdraft gasifier was operated at $850^{\circ} \mathrm{C}$ and equivalence ratio (ER) of 0.25. The concentrations of tar in syngas both before and after passing through the wet scrubber were determined. Chemical compounds in the tar were analysed by GC-MS. The solid residue remaining after gasification was separated into biochar and ash. The biochar was characterized by CHNS/O analyser, FTIR, SEM, and for the iodine number. The compounds in ash were determined by XRF. The results show that biomass type and scrubbing media affected the tar removal efficiency. Scrubbing syngas with WVO had better tar removal efficiency than scrubbing with water. The highest tar removal efficiency with WVO was $82.16 \%$. The tar sample consisted of complex compounds as indicated by GC-MS, and these compounds depended on type of biomass feedstock. The solid residue obtained after gasification process contained biochar (unburned carbon) and ash. Some biochars can be used as solid fuels, depending on carbon content and energy content. The biochar also had a highly porous structure based on SEM imaging, and a high iodine number (930-1134 mg/g). The biochar contained the functional groups $\mathrm{OH}, \mathrm{C}-\mathrm{O}$, and $\mathrm{C}-\mathrm{H}$, as indicated by $\mathrm{FTIR}$. $\mathrm{CaO}, \mathrm{K}_{2} \mathrm{O}, \mathrm{SiO}$, and $\mathrm{MgO}$ were the major components in ash. The spent WVO, biochar, and ash need to be properly managed or utilized for sustainable gasification operations, and these results support that pursuit.
\end{abstract}

Keywords: Biomass; gasification; rubberwood biomass; syngas cleaning; tar removal

ABSTRAK

Penghasilan gas sintesis melalui proses pengegasan masih mencabar kerana kehadiran tar dalam gas sintesis (singas). Tar ini perlu disingkirkan melalui kaedah yang bersesuaian sebelum singas digunakan sebagai bahan api. Selain itu, sisa pepejal yang terhasil selepas proses pengegasan juga perlu diuruskan atau dimusnahkan dengan betul. Oleh demikian, tujuan kajian ini adalah untuk mengkaji tar dan sisa pepejal yang terhasil daripada proses pengegasan biojisim kayu getah, termasuk serpihan kayu getah, pelet kayu getah, arang kayu getah dan campuran kesemua bahan dalam pengegas alir turun. Minyak sayur terpakai dan air telah digunakan sebagai media penggahar. Ciri-ciri sampel biojisim telah dikaji melalui analisis proksimat dan muktamad, dan juga nilai pemanasan tinggi. Sistem pengegas alir turun telah beroperasi pada suhu $850^{\circ} \mathrm{C}$ and nisbah kesetaraan 0.25. Kandungan tar dalam singas sebelum dan selepas melalui media penggahar telah diukur. Sebatian kimia dalam sampel tar telah dianalisis menggunakan GCMS. Sisa baki pepejal selepas proses pengegasan telah dipisah daripada arang bio dan abu. Arang bio telah dicirikan melalui alat CHNS/O, FTIR, SEM, dan nombor iodin. Sebatian dalam abu dianalisis melalui XRF. Keputusan yang diperoleh menunjukkan bahawa jenis biojisim dan media penggahar telah mempengaruhi keberkesanan penyingkiran tar. Penggaharan singas menggunakan minyak sayur terpakai menunjukkan keberkesanan yang lebih baik berbanding dengan air daripada segi penyingkiran tar. Setinggi $82.16 \%$ penyingkiran tar telah tercapai menggunakan minyak sayur terpakai. Sampel tar mengandungi sebatian yang kompleks seperti yang ditunjukkan oleh GC-MS dan komposisi sebatian ini bergantung kepada jenis biojisim. Sisa pepejal terhasil selepas proses pengegasan mengandungi arang bio (karbon tak terbakar) dan abu. Sesetengah arang bio boleh digunakan sebagai bahan api pepejal yang bergantung kepada kandungan karbon dan tenaga. Arang bio yang terhasil juga mempunyai struktur berongga berdasarkan imej 
SEM dan nilai iodin yang tinggi (930-1134 mg/g). Arang bio yang terhasil mengandungi kumpulan berfungsi OH, C-O dan $\mathrm{C}$-H seperti yang ditunjukkan oleh FTIR. $\mathrm{CaO}, \mathrm{K}_{2} \mathrm{O}$, $\mathrm{SiO}$, dan $\mathrm{MgO}$ adalah kandungan utama dalam abu. Minyak sayur terpakai, arang bio dan abu yang telah digunakan perlu diuruskan dengan betul untuk operasi pengegasan yang mampan dan hasil ini menyokong usaha tersebut.

Kata kunci: Biojisim; biojisim kayu getah; pembersihan singas; pembuangan tar; pengegasan

\section{INTRODUCTION}

Rapid depletion of fossil fuel resources and environmental issues caused by their fuel uses are major global challenges. To overcome these issues, biofuels and bioenergy from biomasses, such as wood, residues and wastes, are of great importance in seeking to meet the increasing global energy demands (Abdullahi et al. 2017; Plante et al. 2019; Sikarwar et al. 2017). Moreover, biofuels and bioenergy are economically beneficial to peoples and countries (Amin et al. 2019). Biomass has several advantages among the alternative renewable energy resources that include wind, hydro and solar energy. This is because biomass can be grown, stored, managed and transported, in addition to being environmentally friendly (Kirubakaran et al. 2009; Palamanit et al. 2019; Shrivastava et al. 2020; Sikarwar et al. 2017; Werther et al. 2000; Yokoyama et al. 2000). Generally, most biomasses are lignocellulosic, containing hemicellulose, cellulose and lignin. The composition of lignocellulosic biomass still varies by plant species, maturity stage of the plants, and growth environment and conditions (Anwar et al. 2014; Kumar et al. 2009). The applications of lignocellulosic biomasses as biofuels for bioenergy are of high interest partly because biomass is abundant globally (Müller-Langer \& Kaltschmitt 2015; Nanda et al. 2014; Rajendran et al. 2017).

Thailand is a developing country that heavily relies on fossil fuels for energy, specifically on crude oil, natural gas, and coal. Most of these fuels need to be imported, contributing to low energy security and sustainability, in addition to the environmental impacts. Thus, Thailand has policies to improve the energy security and sustainability and to reduce the greenhouse gas emissions by increasing the utilization of renewable and alternative energy sources. Biomass is among the main candidate renewable energy resources in Thailand and can be applied as biofuels (Khongphakdi et al. 2020; Palamanit et al. 2019; Shrivastava et al. 2020). Thailand has high availability of biomass due to the agro-industries producing rice, palm oil, natural rubber, and rubberwood. Producing these products provides biomass as side products, in the forms of organic residues and wastes. In 2018, the plantation area of rubber trees in Thailand was 3.66 million hectares (Office of Agricultural Economics 2018; Rubber Authority of Thailand 2018) mostly in southern region of the country. The replantation of rubber trees and processing of rubber wood provide many types of biomass, such as rubber tree roots, stumps, branches, leaves, sawdust and bark. These can be applied as feedstocks for bioenergy production. Aside from rubberwood biomass in its raw or unprocessed forms, unburned char or solid residue carbon that remains in bottom ash after combustion of rubberwood in a fixed bed combustor is also an alternative source of energy (James et al. 2012).

Conversion of biomass into biofuels can be performed by mechanical, thermochemical, biochemical, and combined processes (Mckendry 2002a; Shrivastava et al. 2020; Tanger et al. 2013; Tursi 2019). Gasification is a type of thermochemical conversion that is widely applied to produce synthesis gas (syngas) or producer gas (Mckendry 2002b; Molino et al. 2016; Sikarwar et al. 2017; Watson et al. 2018; Widjaya et al. 2018). Such gas is a high-grade fuel and it is relatively easy to use for heat and power generation (Awais et al. 2018; Jia et al. 2017; Kate \& Chaurasia 2018). Gasification is partial oxidation that can be widely applied with many feedstocks, such as biomass, coal, and plastic waste, for producing syngas. The main components in syngas are $\mathrm{CO}, \mathrm{CO}_{2}, \mathrm{CH}_{4}$, and $\mathrm{H}_{2}$ (Abdoulmoumine et al. 2015; Lopez et al. 2018; Pereira et al. 2012; Rasmussen et al. 2020; Watson et al. 2018). The lignocellulosic components in biomass are decomposed to syngas and tar during gasification. There are many factors that influence the quality and quantity of syngas, as well as tar concentration and composition, for example biomass type and composition, type of gasifier, and operating conditions (i.e. temperature and equivalence ratio) (Farzad et al. 2016; Ku et al. 2017; Molino et al. 2016; Pereira et al. 2012; Susastriawan et al. 2017; Widjaya et al. 2018).

Tar is the main problem in commercial applications of syngas. This tar is normally a sticky and black substance containing complex compounds (Han \& Kim 2008; Li \& Suzuki 2009; Valderrama Rios et al. 2018). Tar needs to be eliminated from syngas before use as a gas fuel to prevent damage to pipes, blowers, burners or engines (Valderrama Rios et al. 2018). There are many methods that can be applied to reduce or eliminate tar in syngas, for example thermal treatment, wet scrubbing, bio-filtering, and catalytic treatment (Awais et al. 2018; Fuentes-Cano et al. 2020; Islam 2020; Monir et al. 2020; Nakamura et al. 2015; Shen \& Yoshikawa 2013; Vecchione et al. 2016). These methods have varying tar removal efficiencies. However, wet scrubbing is currently widely applied as it is not too complex, has relatively high 
efficiency, and is cheap and easy to maintain. Nakamura et al. (2015) achieved 73.3\% tar removal using bio-oil as absorbent. Another study reported $80.4 \%$ tar reduction with waste cooking oil (Tarnpradab et al. 2016). Awais et al. (2018) studied gasification of wood chips and corn cobs, and reported tar removal efficiencies in the range $35-74 \%$ when using cyclone, wet scrubber, filter and auxiliary filter. Recently, Monir et al. (2020) showed that tar reduction efficiency significantly increased from 81.87 to $97.25 \%$ when thermal treatment temperature changed from 700 to $1000^{\circ} \mathrm{C}$. Fuentes-Cano et al. (2020) reported that in long tests the catalytic conversion of biomass-derived tars over char was $64-80 \%$. Numerous physical, thermal and chemical processes have been applied for tar elimination, but the removal or elimination of tar from syngas generated from rubberwood biomass still needs studies clarifying alternative processes, absorbing media and cleaning methods (Kaewluan \& Pipatmanomai 2011a, 2011b). Moreover, the solid residue remaining after gasification needs to be properly handled and managed. The recovery of solid residues can be beneficial for economy and sustainability of the gasification process. Therefore, the objectives of this study were to investigate the tar concentration and composition in syngas obtained from gasification of rubberwood chips (RWC), rubberwood pellets (RWP), unburned char (UBC), and their blends in a downdraft gasifier; to determine the efficiency of tar removal using water or waste vegetable oil (WVO) as scrubbing media; and to characterize the solid residue remaining after gasification for potential further applications.

\section{MATERIALS AND METHODS}

\section{RAW MATERIAL PREPARATION}

Isopropanol and acetone used in this study were analytical grade (purity $>99 \%$ ). WVO, ice and salt were purchased from a local market. The RWC was obtained from a factory that produces rubberwood chips, located in Khlongngae, Sadao District, Songkhla Province, Thailand. The size of RWC was about $20 \times 35 \mathrm{~mm}$. The UBC was separated from bottom ash by sieving and the size of UBC was about 10-20 $\mathrm{mm}$. The RWP was obtained from wood pellet production factory located in Rattaphum District, Songkhla Province, Thailand. The RWP had $8 \mathrm{~mm}$ diameter and 20-40 mm length. These biomass samples were dried in a solar greenhouse dryer to reduce the moisture content. The blended samples were prepared by mixing UBC and RWC, or mixing UBC and RWP, both in 50:50 (wt. \%) blend ratio. The prepared samples were kept in airtight bags until use in experiments. The waste vegetable oil (WVO) was filtered to remove suspended particles and was well stirred before use. The overall scheme is presented in Figure 1. Representative samples of biomasses and WVO are shown in Figure S1 (Supplementary data).
SETUP OF DOWNDRAFT GASIFIER AND TAR REMOVAL PROCESS

A schematic diagram of the downdraft gasifier equipped with a tar removal system is shown in Figure S2 (Supplementary data). The downdraft gasifier type was chosen because it provides a low tar concentration in syngas, compared to an updraft or a moving bed gasifier. The downdraft gasifier was fabricated and installed at Prince of Songkla University (PSU), Hat Yai, Songkhla Province, Thailand. The downdraft gasifier was made of high grade steel and the major components of this gasifier include feeding hopper, blower, air supply ring, gas outlet, ignition point, cyclone, control valves, and solid residue collector below the grate, as shown in Figure S2 (a). A wet scrubber system was installed to eliminate tar using water or WVO as scrubbing media. The syngas leaves the gasifier chamber and flows to the cyclone that removes solid particles. Then the syngas flows to the wet scrubber in which it contacts tar absorbing medium that is continuously sprayed through three spray nozzles. The water or WVO is supplied to the nozzles on top of the wet scrubber column by an electrical pump. The tar sampling tray system shown in Figure S2 (b) consists of series of impingement glass bottles. Hot $\left(40^{\circ} \mathrm{C}\right)$ and cold $\left(-20^{\circ} \mathrm{C}\right)$ water baths were used to sample tar from the syngas both before and after passing through the wet scrubber.

The experiment started by feeding $12 \mathrm{~kg}$ of biomass into the gasifier via the hopper, then the lid was tightly closed. The solid residue collection port and all the valves were closed when burning was started at the ignition port. The biomass was initially ignited and left burning for approximately 5-10 min to make sure that the burning was completed. Then, the cover of ignition port was closed and the air supply valve was opened before running the blower. Air was supplied to gasifier at the equivalence ratio (ER) of 0.25 based on preliminary tests. After supplying the air, the temperature in the combustion zone continuously increased and the smoke was visible at the flare pipe, and syngas was burning as a flame. The gasifier was operated to maintain the temperature around $850{ }^{\circ} \mathrm{C}$.

When the gasifier was stabilized at a specific temperature, syngas both before and after passing the wet scrubber was connected to the tar sampling system. While running the gasifier, water or WVO was continuously sprayed to the scrubber column. Each tar sampling train had 6 impingement glass bottles to collect tar before and after the wet scrubber. Hot and cold baths were maintained at $40{ }^{\circ} \mathrm{C}$ and $-20{ }^{\circ} \mathrm{C}$, respectively. The cold bath was prepared by mixing ice, salt and water in an appropriate ratio. The tar sampling glass bottles were filled with $50 \mathrm{~mL}$ of isopropanol, except for the last bottle, which was empty. The collection of tar was performed continuously for $60 \mathrm{~min}$. The flow rate of sampling syngas was maintained at $2 \mathrm{~L} / \mathrm{min}$. The amount of tar in isopropanol was determined by evaporating in 
a rotary vacuum evaporator at $50{ }^{\circ} \mathrm{C}$. The mass of tar in syngas before and after passing the wet scrubber was weighed and then tar removal efficiency was determined from (1). The tar concentration in syngas was determined by (2). The tar sample was diluted with $5 \mathrm{~mL}$ isopropanol and it was analysed for chemical compounds in a GCMS. At the end of each experiment, the gasifier was left to cool and the solid residue was collected. The solid residue was sieved to separate ash and biochar.

Efficiency $(\%)=\frac{\text { weight of tar before scrubber }(\mathrm{g}) \text {-weight of tar after scrubber }(\mathrm{g})}{\text { weight of tar before scrubber }(\mathrm{g})} \times 100$

Tar concertation in syngas $\left(\mathrm{g} / \mathrm{m}^{3}\right)=$ Weight of $\operatorname{tar}(\mathrm{g}) /$ syngas flow rate $\left(\mathrm{m}^{3}\right)$

\section{ANALYTICAL METHODS}

The determination of moisture content, volatile matter, fixed carbon content, and ash content is known as proximate analysis. These components of biomass were determined using a thermogravimetric analyzer (TGA) Marco TGA 701 (LECO, UK) according to the ASTM D7582 procedure (Palamanit et al. 2019; Shrivastava et al. 2020). The elemental components carbon (C), hydrogen $(\mathrm{H})$, nitrogen $(\mathrm{N})$, and sulphur $(\mathrm{S})$ were determined by Thermo Scientific FLASH 2000 Organic Elemental Analyzer (Thermo Scientific, Italy), while the oxygen (O) content was calculated as a difference (Palamanit et al. 2019; Shrivastava et al. 2020). The chemical compounds in the tar were analyzed using Perkin Elmer 600T Gas Chromatography-Mass Spectrometer (GC-MS) equipped with NIST MS 2.0 software. The DB-5MS column used in the $\mathrm{GC}$ was $30 \mathrm{~m}$ long, with $0.25 \mathrm{~mm}$ diameter and $0.25 \mathrm{~mm}$ film thickness. Helium was used as the carrier gas at a flow rate of $1 \mathrm{~mL} / \mathrm{min}$. The oven temperature was set at $65{ }^{\circ} \mathrm{C}$ for $2 \mathrm{~min}$, then it was increased to $300{ }^{\circ} \mathrm{C}$ with a heating rate of $8^{\circ} \mathrm{C} / \mathrm{min}$, and it was maintained at this temperature for $10 \mathrm{~min}$. The injection volume of each sample was $1 \mu \mathrm{L}$.

The functional groups of biochar were determined with a Fourier transform infrared spectrophotometer (FTIR Vortex Bruker, Germany). The samples were scanned over the wavenumber range $400-4000 \mathrm{~cm}^{-1}$. The iodine number, which was correlated to the surface area of biochar, was determined by titrimetry. SEM imaging of biochar was done using Quanta 400 SEM. Ash was separated from biochar mechanically using a $1 \mathrm{~mm}$ sieve and the ash was characterized using X-ray fluorescence (XRF) spectrometry (XRF, Zetium, PANalytical, Netherland).

\section{RESULTS AND DISCUSSION}

\section{BIOMASS COMPOSITION}

The proximate analysis results and elemental compositions of biomass samples are listed in Table 1. It is seen that the moisture contents of all biomass samples were below $10 \%$ due to drying in the solar greenhouse dryer. Biomass with a low moisture content is appropriate feedstock for syngas production via gasification (Demirbaş 2005; Pereira et al. 2012; Sikarwar et al. 2017; Susastriawan et al. 2017). This is because the moisture content of biomass not only influences syngas quality and tar concentration, but it also affects thermal efficiency of the gasifier. Previous studies have reported that gasification of biomass with high moisture provided syngas with low calorific value due to incomplete pyrolysis (McKendry 2002a; Susastriawan et al. 2017). Plis and Wilk (2011) found that the content of $\mathrm{CO}$ in the syngas was higher in the case of dried biomass, while the $\mathrm{CO}_{2}$ content increases with moisture in the feedstock. Additionally, a higher moisture content in the biomass also reduces the molar fraction of combustible components in the syngas, consequently lower its heating value (Antonopoulos et al. 2012). Schuster et al. (2001) showed that the gasifier temperature and syngas yield decreased, while the tar content was higher if the feedstock contained more than 30 wt. \% moisture. Moreover, gasification of biomass with high moisture content also consumes extra heat to evaporate moisture (Brammer \& Bridgwater 2002). In practice, gasification of biomass should be performed with feedstock that has a suitable moisture content to reduce the losses of thermal energy from the gasifier. The moisture content limits for gasifier feedstock depend on the type of gasifier used. The highest moisture content for a downdraft gasifier is generally considered to be $25 \%$ wet basis, and not higher than $50 \%$ for an updraft gasifier (Seggiani et al. 2012).

The volatile matter of RWC and RWP was $74.4 \%$ and $76 \%$, respectively, while the UBC had very low volatile matter content $(19.0 \%)$ in comparison. This is because the UBC was already decomposed during the combustion of rubberwood in a boiler system. The volatile matter of UBC used in this study was similar to the volatile matter of biochar from pyrolysis (Palamanit et al. 2019). The presence of volatile matter in biomass indicates the degree of combustibility of a solid fuel and it also indicates the gas and tar generation during gasification. It is well known that high volatile matter in biomass promotes gas and tar generation. Watson et al. (2018) reported that agricultural residues tend to produce a large amount of tar because they tend to have high volatile matter contents. Considering the fixed carbon content of biomass samples, the contents in RWC, RWP, and UBC were $16.8 \%, 15 \%$ and $50.6 \%$, respectively. The low volatile matter in UBC led to a high fixed carbon content. The fixed carbon of biomass is the component that can be converted into biochar after devolatilization. The fixed carbon content of biomass also indicates the rate of gasification and the syngas yield (Basu 2010; Watson et al. 2018). The inorganic components in biomass are 


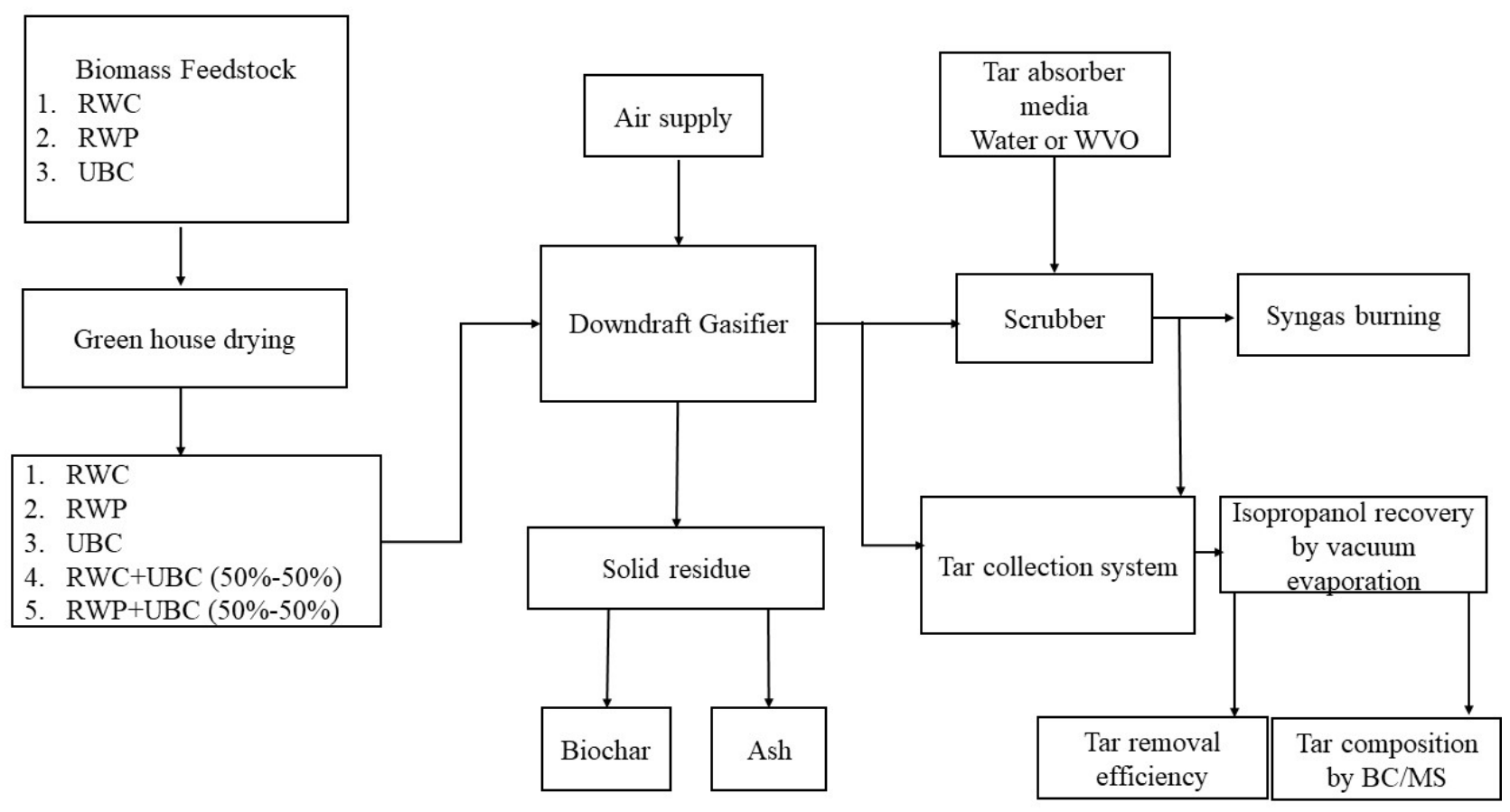

FIGURE 1. Overall processing scheme

TABLE 1. Composition and heating value of rubberwood biomass samples

\begin{tabular}{lccc}
\hline Compositional analysis & \multicolumn{3}{c}{ Biomass sample } \\
\hline "Proximate analysis & RWC & RWP & UBC \\
Moisture & 6.4 & 7.0 & 8.2 \\
Volatile matters & 74.4 & 76.0 & 19.0 \\
Fixed carbon & 16.8 & 15.0 & 50.6 \\
Ash & 2.4 & 2.0 & 22.2 \\
"Ultimate analysis & & & \\
C & 45.50 & 44.80 & 58.50 \\
H & 5.80 & 5.70 & 1.20 \\
$\mathrm{~N}$ & 0.20 & 0.20 & 0.20 \\
$\mathrm{~S}$ & 0.02 & 0.08 & 0.05 \\
$* \mathrm{O}$ & 39.68 & 40.22 & 9.65 \\
$\mathrm{HHV}(\mathrm{MJ} / \mathrm{kg})$ & 17.80 & 17.40 & 19.30 \\
\hline
\end{tabular}

$\# \%$ wt. as received basis, ${ }^{*}$ by difference $(\mathrm{O}=100-($ Moisture $+\mathrm{Ash}+\mathrm{C}+\mathrm{H}+\mathrm{N}+\mathrm{S}))$ 
considered ash. The RWC and RWP used in this study had low ash contents $(2-2.40 \%)$, while the ash content of UBC was high $(22.2 \%)$ due to loss of volatile matters. Biomass with a high ash content not only provides high ash amount after gasification, but also causes problems such as reactor plugging, sintering of catalyst, and need for proper management or disposal of ash residue. Di Gregorio et al. (2014) also reported that when the ash content of the feedstock increased from $17.2 \%$ to $25.1 \%$, the gasification efficiency decreased from $63 \%$ to $33 \%$, and the contents of $\mathrm{H}_{2}$ and $\mathrm{CO}$ decreased significantly, resulting in a loss of higher heating value (HHV) of the syngas. Thus, proximate analysis helps choose appropriate operating conditions, catalysts and gasifier configurations (Watson et al. 2018).

Regarding the elemental composition of biomass samples, ultimate analysis showed that the contents of carbon, hydrogen, nitrogen Sulphur, and oxygen of RWC, RWP, and UBC were 44.8-58.5\%, 1.2-5.84\%, 0.2, $0.02-0.08 \%$, and $9.65-40.22 \%$, respectively. The UBC contained more carbon than RWC and RWP, while the hydrogen content of UBC was the lowest. This is due to the loss of volatile matter from the UBC. The results of ultimate analysis are consistent with the proximate analysis results. Ultimate analysis is generally performed to assess the potential of a biomass as solid fuel for bioenergy. Normally, biomass with high carbon and hydrogen contents provides a high HHV. The results of proximate and ultimate analysis of feedstocks in this study are similar to previous studies (Abdullahi et al. 2017; García et al. 2013; Johari et al. 2014). For gasification, high amounts of carbon and oxygen in the biomass contribute to $\mathrm{CO}_{2}$ and $\mathrm{CO}$ formation during gasification, and also increase the yields of $\mathrm{CH}_{4}$ and $\mathrm{H}_{2}$, if the gasifier is operated at suitable conditions. Low nitrogen and sulphur contents in biomass help avoid the formation of $\mathrm{NO}_{\mathrm{x}}$ and $\mathrm{SO}_{\mathrm{x}}$ (Mishra \& Mohanty 2018). Most of the nitrogen during gasification is in the forms of organic complexes and therefore, reacts with hydrogen, forming ammonia and even hydrogen cyanide (Watson et al. 2018). A small amount of nitrogen is retained in the unreacted solid residues. In the case of sulphur, it is often emitted in the form of $\mathrm{H}_{2} \mathrm{~S}$, which leads to difficulty in gas treatment and separation (Watson et al. 2018). Regarding oxygen, it is seen that UBC had the lowest oxygen content, due to thermal decompostion of lignocellulosic components in the biomass. The low oxygen content of UBC led to high HHV as seen in Table 1. The HHVs of RWC, RWP, and UBC were 17.80, 17.40, and $19.30 \mathrm{MJ} / \mathrm{kg}$.

\section{TAR CONCENTRATION IN SYNGAS AND TAR REMOVAL} EFFICIENCY

In practice, condensation of tar on cool surfaces tends to occur in ducts, heat exchangers, filters and blowers, and is the big problem to commercial syngas applications. Tar not only deposits on and fouls equipment, but it also decreases the process efficiency and increases system operational costs (Valderrama Rios et al. 2018). Thus, tar in syngas needs to be reduced or eliminated to address these problems. The amount of tar in syngas prior to its application in an internal combustion engine or a gas turbine should be below 100 and $5.0 \mathrm{mg} / \mathrm{m}^{3}$, respectively (Valderrama Rios et al. 2018).

Table 2 shows the tar concentration in syngas obtained from different biomasses by gasification, at inlet and outlet of a wet scrubber using water and WVO as the scrubbing media. The results indicated that gasification of the selected biomass in a downdraft gasifier provided tar concentrations of $1.61-20.66 \mathrm{~g} / \mathrm{m}^{3}$. The type of biomass affected tar concentration. Gasification of RWP and RWC showed the most tar, followed by the biomass blends. The syngas from UBC had lowest tar concentration. The tar concentration in syngas from these biomasses was attributed to their volatile matter, which is emitted as both gases and vapors, and the latter ones can be condensed. The UBC feedstock had low volatile matter content, resulting in less tar formation during gasification. When the tar was eliminated by wet scrubber, it can be observed in Table 2 that the tar concentration in syngas was significantly reduced both with water and with WVO scrubbing media, for all the feedstocks. Interestingly, syngas cleaned with WVO had less tar that after water scrubbing. The scrubbing media had different abilities to capture or adsorb specific compounds in the tar. Although the tar components have low solubility in water, the decrease in gravimetric tar due to water scrubbing can be attributed to condensation of tar when contacting sprayed water. The low temperature of water scrubber with respect to the temperature of entering gas condensed tar as a separate phase on water surfaces, and this could be observed in the water container. The high tar removal efficiency of WVO is due to the tar solubility in oil. High efficiency of tar removal on using oil scrubber has been found in many studies. Phuphuakrat et al. (2011) reported $31.8 \%$ tar removal efficiency on using water as scrubbing medium, whereas the efficiency was $60.4 \%$ with vegetable oil. Moreover, the tar removal efficiency of cooking oil or vegetable oil (fresh or waste) has been investigated in many studies, such as Ahmad et al. (2016), Bhoi et al. (2015), Nakamura et al. (2016), Paethanom et al. (2013), Tarnpradab et al. (2016), Thapa et al. (2017), and Unyaphan et al. (2017). They indicate that these oils provide high tar removal efficiencies ranging from $80 \%$ to $98 \%$, depending on type of oil and operating conditions.

In this study, the overall impact of tar removal efficiency was calculated and the results showed that it was in the range of $48.45-82.16 \%$, as shown in Figure 2. The highest removal efficiency of tar was obtained in case of the mixture of RWP+UBC (50:50). These results showed that wet scrubbing eliminated a large amount of tar when RWP or RWC was used as feedstock. The wet scrubber can also help remove metals and dust particles that remain in the syngas stream (Stevens 2001). Considering the 
tar removal efficiencies of water and WVO, it was clear that the WVO was the more efficient choice. The high tar removal efficiency of the oil-based scrubbing media is attributed to lipophilicity characteristics of oil. This helps dissolve the non-polar hydrocarbons of tar (Ahmad et al. 2016; Paethanom et al. 2012). Normally, tar compounds are lipophilic in nature and can mix well with vegetable oils, as these oils have saturated and unsaturated fatty acids (Ahmad et al. 2016). Thus, WVO was more efficient for the one-ring aromatic hydrocarbons and other light tar components. According to the results of this study, on employing WVO as the scrubbing medium the gravimetric tar removal increased to $80.84 \%$ from $68.51 \%$ for water scrubbing, with RWC feedstock. Similar efficiency in tar reduction was observed with every rubberwood feedstock, as WVO adsorbed $76.62 \%$ of the tar from RWP, which was $12 \%$ more efficient than with water scrubbing. In the case of UBC, WVO could reduce tar by $62 \%$ and was $13.79 \%$ more efficient than water.

\section{CHEMICAL COMPOUNDS IN TAR}

The sample of tar in syngas before passing through the wet scrubber was subjected to GC-MS. The results showed that the main tar compounds in syngas differed by type of biomass. The main chemical compounds in tar obtained from gasification of RWC and RWP included aniline-1-(13)C, 13-docosenamide, (Z)-, phorbol, naphthalene, 2-phenyl-, 3-bromobenzoic acid, octadecyl, phenol, and benzothiazole. In the case of $\mathrm{UBC}$, the tar was mainly composed of 3,5-dimethoxy4-hydroxytoluene, phenol, 2-methoxy-4-(1-propenyl)-, 5-tert-butylpyrogallol, dimethoxy propyl and phenol, 2,6-dimethoxy-. These results showed that tar components were complex compounds, such as amines, furans and aromatics, and phenols, depending on biomass type. The composition of tar in syngas from UBC was different from RWC and RWP, because UBC had low volatile matter content as seen in proximate analysis. Some previous studies have indicated that there are five classes of compounds in tar, including GC-undetectable tar, heterocyclic, light aromatic (1 ring), light PAHs compounds (2-3 rings) and heavy PAHs compounds (4-7 rings) (Han \& Kim 2008; Li \& Suzuki 2009; Valderrama Rios et al. 2018). However, Corella et al. (2003) classified tar compounds to 6 categories, including benzene; one-ring compounds (excluding benzene): toluene, xylenes, styrene, indene, methyl-indene, indan, thiophene, ethyl-benzene, methylbenzene; naphthalene; two-ring compounds (excluding naphthalene): methylnaphthalenes, biphenyls, acenaphthene, acenaphthylene, fluorene, benzofurans, methyl-benzofurans; three and four-ring compounds: Anthracene, phenanthrene, fluoranthene, pyrene, dibenzofuran; and phenolic compounds such as phenols and methyl-phenols. Milne et al. (1998) reported that the primary tar compounds are generated during pyrolysis stage in gasification by the thermal decomposition of biomass, which produces acids, sugars, alcohols, ketones, aldehydes, phenols, catechols, guaiacols, syringols, furans, and oxygenates. When the temperature increased beyond $500{ }^{\circ} \mathrm{C}$, secondary tar was formed as a result of primary tar rearrangement, forming heavier molecules such as phenols and olefins. The tar alkyl tertiary products include methyl derivatives of aromatic compounds, such as methyl acenaphthylene, methyl naphthalene, toluene and indene. The condensation of tertiary aromatics form PAHs without substituent atoms, such as benzene, naphthalene, acenaphthylene, anthracene, phenanthrene, and pyrene (Milne et al. 1998). Normally, the tar chemical compounds depend on many factors, such biomass type and compositions, gasifier type, and operating conditions (such as temperature and ER). Knowing the tar composition helps select appropriate tar removal methods.

ELEMENTAL COMPOSITION OF BIOCHAR

The solid residue remaining after gasification was separated into biochar and ash. These solid residues were characterized to identify potential applications. The elemental compositions of biochar samples are presented in Table 3. It can be observed that biochar of UBC and blended biomasses had higher carbon contents than biochars from RWC and RWP. This high carbon content indicates high potential for use as solid fuel. A high carbon content is also suitable for carbon sequestration. When UBC is already free from volatiles, the carbon in UBC and blended samples is expected to become higher on heating for gasification. Biochars can be categorized into three classes based on carbon content: 10-30\%; $30-60 \%$; and more than $60 \%$. The biochars from UBC and blended samples are in class 3, while biochars from RWC and RWP are in class 2. The high carbon contents remaining in biochar after gasification are similar to those in biochar from pyrolysis (Palamanit et al. 2019). The $\mathrm{H} / \mathrm{C}$ ratio explains the degree of aromatization and bonding arrangement in biochar. A low value $\mathrm{H} / \mathrm{C}$ ratio leads to stronger aromatization, where the carbon in biochar is predominantly unsaturated and $\mathrm{C}$ atoms are bonded with other carbon atoms.

The higher heating value (HHV) of a biochar is a crucial factor that needs to be considered for further biochar applications. It can be seen that biochar obtained from blends of UBC with RWC or UBC with RWP had greater HHV than those from single feedstocks. The heating value of biochar was in the range of 24-25 MJ/ $\mathrm{kg}$, which is relatively high and appropriate for a solid fuel. The heating values of biochars from RWC and RWP were low but still good for solid fuel uses. However, their applications to soil amendment or wastewater treatment can be attractive alternatives.

\section{CHARACTERIZATION OF BIOCHAR BY FTIR}

The functional groups in biochar need to be identified if a biochar is considered for use as adsorbent. The functional groups in biochars from the various feedstocks were determined by FTIR analysis, as shown in Figure 3. The 
FTIR spectra show many peaks from different functional groups. The peak in the range of $3300-3400 \mathrm{~cm}^{-1}$ is for OH group (Jadhav et al. 2019; Liang et al. 2019). The peaks at $2800-2900 \mathrm{~cm}^{-1}$ are assigned to alkanes. The peaks in the range $1900-2000 \mathrm{~cm}^{-1}$ belong to NCS compounds. The peaks at $1600-1700 \mathrm{~cm}^{-1}$ are for amide, secondary amines, and nitrates. The peaks at 1300-1400 $\mathrm{cm}^{-1}$ belong to alcohols, while at $900-1000 \mathrm{~cm}^{-1}$ the peaks indicate C-O compounds (Guo \& Bustin 1998). The peaks at $700-800 \mathrm{~cm}^{-1}$ correspond to aromatic $\mathrm{C}-\mathrm{H}$ stretching (Hossain et al. 2011). It is observed that all biochars had some variation in the spectra, which is attributed to the gasification process. However, all biochars exhibited similar trends as regards the functional groups. The biochar surface was rich in O-containing functional groups, which are highly desired for pollutant adsorption such as in treatment of wastewater, dyes or oil (Jindo et al. 2014).

\section{SURFACE FEATURES AND IODINE NUMBERS OF BIOCHARS}

Figure 4 shows SEM images of the biochar samples from gasification of RWC, RWP, UBC, RWC+UBC, and RWP+UBC. It is seen that the surfaces of biochar are rough and porous, which indicates good potential for application as adsorbents. The surface of biochar from UBC clearly shows large pores, which may be due to two high-temperature treatments. The UBC was already heated in a boiler system, which generated pores. The surface features of biochars in this study are similar to those in Bensidhom et al. (2018) and Palamanit et al. (2019). Moreover, the biochar can also be used as tar absorbing medium after treatment. Regarding the iodine number, it is another biochar property important for application as adsorbents (Bamdad et al. 2018). This property is strongly related to specific surface area. Iodine numbers of the biochars from gasification of RWC, RWP, UBC, RWC+UBC, and RWP+UBC were 925, 1022, 1018, 1130, and $934 \mathrm{mg} / \mathrm{g}$, respectively. The biochar from RWC+UBC showed the highest iodine number suggesting this possibly had the highest surface area among the biochar samples. A high iodine number suggests that the biochar can be an excellent adsorbent and possibly has high specific surface. The results indicate that biochars from all types of biomass tested may be good as adsorbents, and these results are well supported by a previous study on biochar preparation and activation for use as an adsorbent (Saad et al. 2019).

\section{CHEMICAL COMPOSITION OF ASH}

The ash that was separated from biochar after finished gasification of the different feedstocks was analyzed for chemical composition, and the results are shown in Table 4. It is seen that the main chemical components in the ash samples were $\mathrm{CaO}(24.28-41.78 \%), \mathrm{SiO}$ (7.34$14.87 \%), \mathrm{K}_{2} \mathrm{O}$ (5.64-12.85\%), and $\mathrm{MgO}$ (3.70-5.47\%), while the $\mathrm{Cl}$ content was low $(0.03-0.08 \%)$. These results indicate that rubberwood biomass has a high content of mineral elements, including $\mathrm{K}, \mathrm{Ca}, \mathrm{Si}$, and $\mathrm{Mg}$. High contents of these elements are found in many biomasses, of both wood-based and herbaceous types, such as wood pellets, olive husks, wheat straws, corn stalks, and eucalyptus bark (Chen et al. 2015; Li et al. 2015; Nunes et al. 2016; Yao et al. 2020; Yu et al. 2014). The major and minor elements in biomass normally come from the minerals in soil or feeding nutrients. High contents of the mentioned elements are disadvantageous to combustion or gasification. A high concentration of $\mathrm{K}$ in the biomass tends to cause formation of chemical compounds with low melting points, which leads to severe slagging and fouling on the heating surfaces, limiting attractiveness of the biomass (Nunalapati et al. 2007; Zhu et al. 2014). In biomass gasification, operation of the gasifier at a high temperature is also risk potentially causing slagging and fouling in reaction chamber, syngas pipe, and cooling system. However, the results of ash analysis showed that most of the major and minor elements in biomass still remained in the forms of oxides $\left(\mathrm{SiO}_{2}, \mathrm{Al}_{2} \mathrm{O}_{3}, \& \mathrm{TiO}_{2}\right)$ and alkaline oxides $\left(\mathrm{CaO}, \mathrm{MgO}, \mathrm{Na}_{2} \mathrm{O}, \& \mathrm{~K}_{2} \mathrm{O}\right)$. The presence of these compounds in ash indicates that this ash can be applied in construction materials or it can be applied as bio-fertilizer. Such potential applications would need to be properly tested.

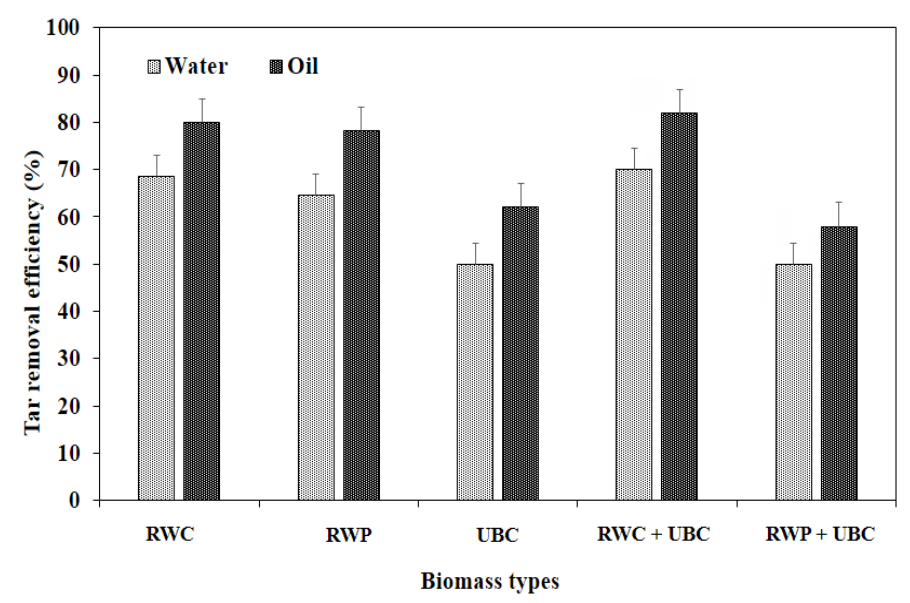

FIGURE 2. Tar removal efficiency of water and WVO scrubbing for syngas from different biomasses 
TABLE 2. Tar concentration in syngas before and after wet scrubbing system

\begin{tabular}{lcccc}
\hline \multirow{2}{*}{ Feedstock } & \multicolumn{2}{c}{ Water scrubbing } & \multicolumn{2}{c}{ Oil scrubbing } \\
\cline { 2 - 5 } & $\mathrm{BS}\left(\mathrm{g} / \mathrm{m}^{3}\right)$ & $\mathrm{AS}\left(\mathrm{g} / \mathrm{m}^{3}\right)$ & $\mathrm{BS}\left(\mathrm{g} / \mathrm{m}^{3}\right)$ & $\mathrm{AS}\left(\mathrm{g} / \mathrm{m}^{3}\right)$ \\
\hline RWC & 10.83 & 3.41 & 20.41 & 3.91 \\
RWP & 10.85 & 3.83 & 20.66 & 4.83 \\
UBC & 1.61 & 0.83 & 2.41 & 0.91 \\
RWC+UBC & 2.75 & 0.84 & 11.66 & 2.08 \\
RWP+UBC & 5.01 & 2.50 & 5.41 & 2.25 \\
\hline
\end{tabular}

$\mathrm{BS}=$ before scrubber, $\mathrm{AS}=$ after scrubber

TABLE 3. Elemental compositions of biochars and higher heating values

\begin{tabular}{lcccccc}
\hline Biochar & $\mathrm{C}$ & $\mathrm{H}$ & $\mathrm{N}$ & $\mathrm{S}$ & $\mathrm{H} / \mathrm{C}$ & $\mathrm{HHV}$ \\
\hline RWC & 46.1 & 2.1 & 0.9 & 2.3 & 0.55 & 10.5 \\
RWP & 24.1 & 0.5 & 0.1 & 0.07 & 0.28 & 7.5 \\
UBC & 77.6 & 1.0 & 0.2 & 0.52 & 0.15 & 14.0 \\
RWC+UBC & 75.9 & 1.6 & 0.3 & 1.4 & 0.25 & 25.6 \\
RWP+UBC & 74.2 & 1.0 & 0.3 & 0.3 & 0.17 & 24.2 \\
\hline
\end{tabular}

Unit of $\mathrm{HHV}$ was $\mathrm{MJ} / \mathrm{kg}$

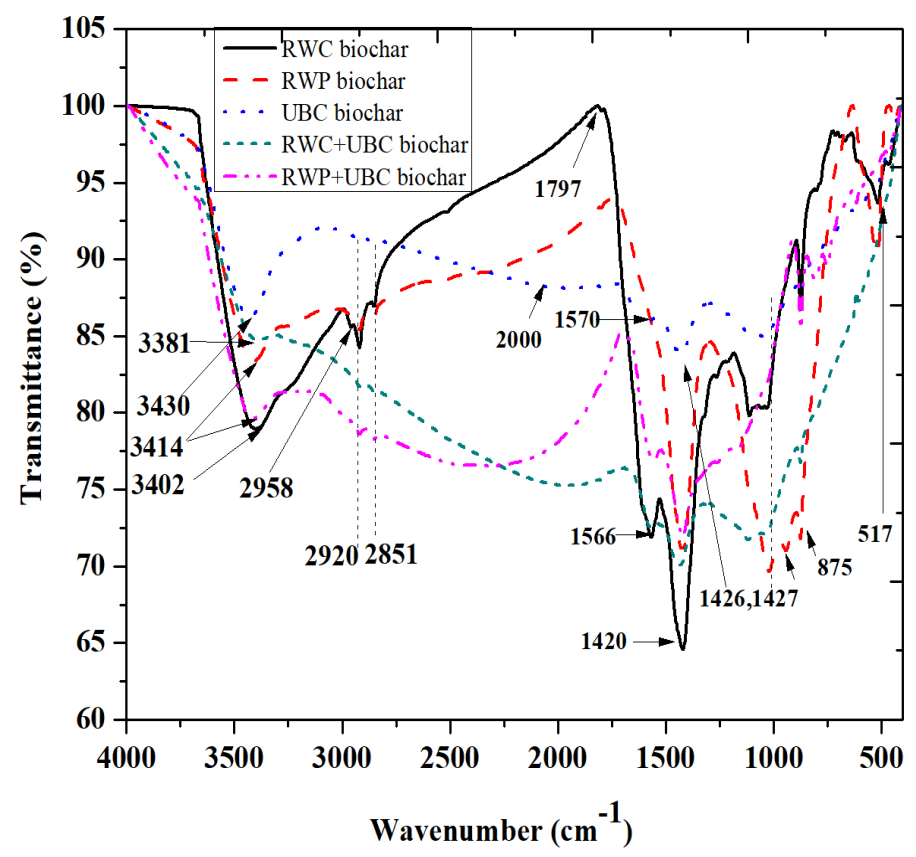

FIGURE 3. FTIR profiles of biochar obtained after gasification of different feedstocks 


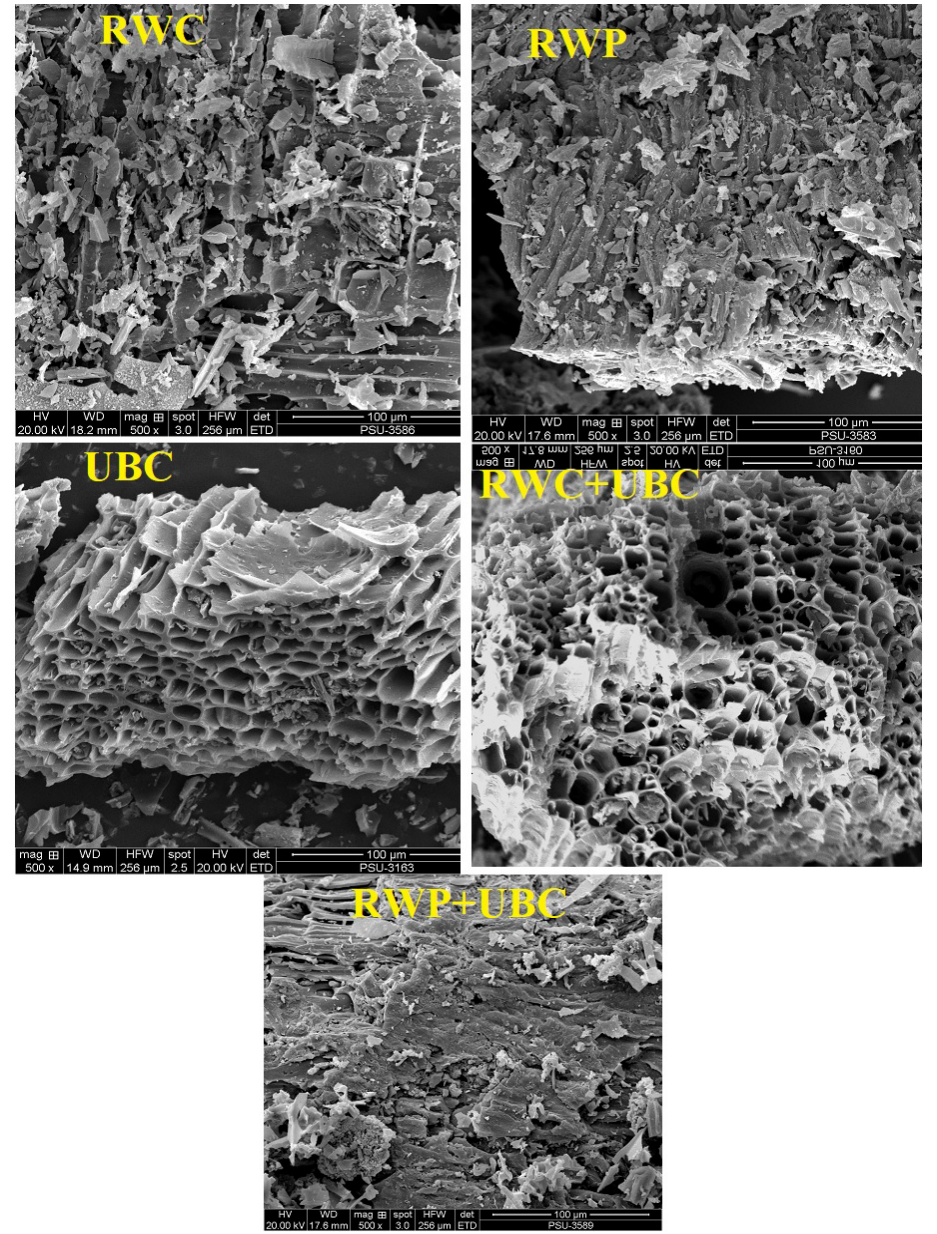

FIGURE 4. SEM images of biochar derived from gasification of different feedstocks

TABLE 4. XRF analysis results of ash obtained after gasification of different feedstocks

\begin{tabular}{lccccc}
\hline \multirow{2}{*}{ Compound } & \multicolumn{5}{c}{ Feedstock } \\
\cline { 2 - 5 } $\mathrm{Na}_{2} \mathrm{O}$ & $\mathrm{RWC}$ & $\mathrm{RWP}$ & $\mathrm{UBC}$ & $\mathrm{RWC}+\mathrm{UBC}$ & $\mathrm{RWP}+\mathrm{UBC}$ \\
$\mathrm{MgO}$ & 0.13 & 0.10 & 0.06 & 0.07 & 0.07 \\
$\mathrm{Al}_{2} \mathrm{O}_{3}$ & 4.34 & 5.47 & 3.70 & 5.29 & 5.19 \\
$\mathrm{SiO}_{2}$ & 0.58 & 1.15 & 0.91 & 1.28 & 1.07 \\
$\mathrm{P}_{2} \mathrm{O}_{5}$ & 7.34 & 10.27 & 9.34 & 14.87 & 11.18 \\
$\mathrm{SO}_{3}$ & 2.02 & 2.65 & 1.79 & 2.90 & 2.61 \\
$\mathrm{Cl}$ & 1.07 & 1.10 & 0.60 & 0.68 & 1.11 \\
$\mathrm{~K}_{2} \mathrm{O}$ & 0.08 & 0.07 & 0.03 & 0.03 & 0.05 \\
$\mathrm{CaO}$ & 12.12 & 12.85 & 5.64 & 6.01 & 8.64 \\
$\mathrm{TiO}_{2}$ & 34.53 & 28.77 & 24.28 & 41.78 & 35.57 \\
$\mathrm{Cr}_{2} \mathrm{O}_{3}$ & 0.09 & 0.14 & 0.10 & 0.13 & 0.11 \\
$\mathrm{MnO}_{\mathrm{Fe}} \mathrm{O}_{3}$ & 0.02 & 0.02 & 0.01 & 0.01 & 0.01 \\
$\mathrm{NiO}_{\mathrm{CuO}}$ & 0.65 & 0.43 & 0.41 & 0.68 & 0.57 \\
$\mathrm{ZnO}$ & 4.10 & 3.81 & 2.02 & 1.61 & 1.24 \\
$\mathrm{Rb}_{2} \mathrm{O}$ & 0.02 & 0.02 & 0.01 & 0.02 & 0.02 \\
$\mathrm{SrO}_{\mathrm{ZrO}}$ & 0.03 & 0.02 & 0.02 & 0.02 & 0.02 \\
$\mathrm{BaO}_{2}$ & 0.21 & 0.08 & 0.03 & 0.07 & 0.07 \\
\hline & 0.08 & 0.07 & 0.03 & 0.04 & 0.04 \\
& 0.15 & 0.09 & 0.08 & 0.14 & 0.11 \\
& 0.01 & 0.01 & 0.01 & 0.01 & 0.01 \\
& 0.08 & 0.05 & 0.04 & 0.08 & 0.06 \\
\hline
\end{tabular}




\section{CONCLUSION}

Tar and solid residues were investigated, generated from gasification of rubberwood biomasses of various types in a downdraft gasifier. The biomasses tested were rubberwood chips (RWC), rubberwood pellets (RWP), rubberwood unburned char (UBC), and some blended samples. Waste vegetable oil (WVO) and water were used as alternatives in wet scrubbing. The downdraft gasifier was operated at $850{ }^{\circ} \mathrm{C}$ and an equivalence ratio (ER) of 0.25 . The tar concentration in syngas before and after wet scrubbing were determined and the tar compounds were analysed by GC-MS. The remaining solid residue from gasification was separated into biochar and ash by sieving. The biochar was investigated for chemical elements, surface features (SEM imaging), functional groups (FTIR), and iodine number. The ash components were determined by XRF. The results indicate that biomass type and scrubbing medium choice affected the tar removal efficiency. WVO provided the highest tar removal efficiency $(82.16 \%)$. The main chemical compounds in tar were complex compounds that depended on biomass feedstock. The solid residue remaining after gasification had both biochar (unburned carbon) and ash. Some of the biochars had potential for use as solid fuels, as indicated by carbon content and energy content. The biochars also had highly porous structures seen in SEM images and iodine numbers (930-1134 mg/g). The biochars had $\mathrm{O}-\mathrm{H}$ functional groups indicated by FTIR. The oxides $\mathrm{CaO}, \mathrm{K}_{2} \mathrm{O}, \mathrm{SiO}_{2}$, and $\mathrm{MgO}$ were the major components in ash. These results support beneficial use rubberwood biomass via gasification to syngas, by applying WVO to eliminate tar in the syngas, as well as contributing to the management of spent WVO, biochar, and ash.

\section{ACKNOWLEDGEMENTS}

This research was financially supported by Thailand's Education Hub for Southern Region of ASEAN Countries, granted by the Graduate School, Prince of Songkla University (PSU), Hat Yai, Songkhla, Thailand. The authors are also thankful to Sustainable Energy Management Program, Faculty of Environmental Management, PSU, for providing all facilities and supporting staff to accomplish this work.

\section{REFERENCES}

Abdullahi, N., Sulaiman, F. \& Safana, A.A. 2017. Bio-oil and biochar derived from the pyrolysis of palm kernel shell for briquette. Sains Malaysiana 46(12): 2441-2445.

Abdoulmoumine, N., Adhikari, S., Kulkarni, A. \& Chattanathan, S. 2015. A review on biomass gasification syngas cleanup. Applied Energy 155: 294-307.

Ahmad, N.A. \& Zainal, Z.A. 2016. Performance and chemical composition of waste palm cooking oil as scrubbing medium for tar removal from biomass producer gas. Journal of Natural Gas Science and Engineering 32: 256-261.

Amin, M., Chetpattananondh, P. \& Ratanawilai, S. 2019. Application of extracted marine Chlorella sp. residue for bio-oil production as the biomass feedstock and microwave absorber. Energy Conversion and Management 195: 819-829.

Antonopoulos, I.S., Karagiannidis, A., Gkouletsos, A. \& Perkoulidis, G. 2012. Modelling of a downdraft gasifier fed by agricultural residues. Waste Management 32: 710-718.

Anwar, Z., Gulfraz, M. \& Irshad, M. 2014. Agro-industrial lignocellulosic biomass a key to unlock the future bio-energy: A brief review. Journal of Radiation Research and Applied Sciences 7(2): 163-173.

Awais, M., Li, W., Arshad, A., Haydar, Z., Yaqoob, N. \& Hussain, S. 2018. Evaluating removal of tar contents in syngas produced from downdraft biomass gasification system. International Journal of Green Energy 15(12): 724-731.

Bamdad, H., Hawboldt, K. \& MacQuarrie, S. 2018. A review on common adsorbents for acid gases removal: Focus on biochar. Renewable and Sustainable Energy Reviews 81: 1705-1720.

Basu, P. 2010. Biomass Gasification and Pyrolysis: Practical Design and Theory. 1st ed. New York: Academic Press.

Bensidhom, G., Hassen-Trabelsia, A.B., Alper, K., Sghairoun, M., Zaafouri, K. \& Trabelsi, I. 2018. Pyrolysis of date palm waste in a fixed-bed reactor: Characterization of pyrolytic products. Bioresource Technology 247: 363-369.

Bhoi, P.R., Huhnke, R.L., Kumar, A., Payton, M.E., Patil, K.N. \& Whiteley, J.R. 2015. Vegetable oil as a solvent for removing producer gas tar compounds. Fuel Processing Technology 133: 97-104.

Brammer, I.G. \& Bridgwater, A.V. 2002. The influence of feed stock drying on the performance and economics of a biomass gasifier-engine CHP System. Biomass and Bioenergy 22(4): 271-281.

Chen, M., Yu, D. \& Wei, Y. 2015. Evaluation on ash fusion behaviour of eucalyptus bark/lignite blends. Powder Technology 286: 39-47.

Corella, J., Caballero, M.A., Aznar, M.P. \& Brage, C. 2003. Two advanced models for the kinetics of the variation of the tar composition in its catalytic elimination in biomass gasification. Industrial \& Engineering Chemistry Research 42(13): 3001-3011.

Demirbaş, A. 2005. Thermochemical conversion of biomass to liquid products in the aqueous medium. Energy Source 27(13): 1235-1243.

Di Gregorio, F., Santoro, D. \& Arena, U. 2014. The effect of ash composition on gasification of poultry wastes in a fluidized bed reactor. Waste Management \& Research 32(4): 323-330.

Farzad, S., Mandegari, M.A. \& Görgens, J.F. 2016. A critical review on biomass gasification, co-gasification, and their environmental assessments. Biofuel Research Journal 12: 483-495.

Fuentes-Cano, D., Von Berg, L., Diéguez-Alonso, A., Scharler, R., Gómez-Barea, A. \& Anca-Couce, A. 2020. Tar conversion of biomass syngas in a downstream char bed. Fuel Processing Technology 199: 106271.

García, R., Pizarro, C., Lavín, A.G. \& Bueno, J.L. 2013. Biomass proximate analysis using thermogravimetry. Bioresource Technology 139: 1-4.

Guo, Y. \& Bustin, R. 1998. FTIR spectroscopy and reflectance of modern charcoals and fungal decayed woods: Implications for studies of inertinite in coals. International Journal of Coal Geology 37(1-2): 29-53.

Han, J. \& Kim, H. 2008. The reduction and control technology of tar during biomass gasification/pyrolysis: An overview. Renewable and Sustainable Energy Reviews 12(2): 397-416. 
Hossain, M.K., Strezov, V., Chan, K.Y., Ziolkowski, A. \& Nelson, P.F. 2011. Influence of pyrolysis temperature on production and nutrient properties of wastewater sludge biochar. Journal of Environmental Management 92(1): 223-228.

Islam, M.W. 2020. A review of dolomite catalyst for biomass gasification tar removal. Fuel 267: 117095.

Jadhav, A., Ahmed, I., Baloch, A.G., Jadhav, H., Nizamuddin, S., Siddiqui, M.T.H. \& Mubarak, N.M. 2019. Utilization of oil palm fronds for bio-oil and bio-char production using hydrothermal liquefaction technology. Biomass Conversion and Biorefinery. https://doi.org/10.1007/s13399-01900517-y.

James, A.K., Thring, R.W., Helle, S. \& Ghuman, H.S. 2012. Ash management review-Applications of biomass bottom ash. Energies 5(10): 3856-3873.

Jia, S., Ning, S., Ying, H., Sun, Y., Xu, W. \& Yin, H. 2017. High quality syngas production from catalytic gasification of woodchip char. Energy Conversion and Management 151: 457-464.

Jindo, K., Mizumoto, H., Sawada, Y., Sanchez-Monedero, M.A. \& Sonoki, T. 2014. Physical and chemical characterization of biochars derived from different agricultural residues. Biogeosciences 11(23): 6613-6621.

Johari, A., Mat, R., Alias, H., Hashim, H., Hassim, M.H., Zakaria, Z.Y. \& Rozainee, M. 2014. Combustion characteristics of refuse derived fuel (rdf) in a fluidized bed combustor. Sains Malaysiana 43(1): 103-109.

Kaewluan, S. \& Pipatmanomai, S. 2011a. Gasification of high moisture rubber woodchip with rubber waste in a bubbling fluidized bed. Fuel Processing Technology 92(3): 671-677.

Kaewluan, S. \& Pipatmanomai, S. 2011b. Potential of synthesis gas production from rubber wood chip gasification in a bubbling fluidised bed gasifier. Energy Conversion and Management 52(1): 75-84.

Kate, G.U. \& Chaurasia, A.S. 2018. Gasification of rice husk in two-stage gasifier to produce syngas, silica and activated carbon. Energy Sources, Part A: Recovery, Utilization and Environmental Effects 40(4): 466-471.

Kirubakaran, V., Sivaramakrishnan, V., Nalini, R., Sekar, T., Premalatha, M. \& Subramanian, P. 2009. A review on gasification of biomass. Renewable and Sustainable Energy Reviews 13(1): 179-186.

Khongphakdi, P., Palamanit, A., Phusunti, N., Tirawanichakul, Y. \& Shrivastava, P. 2020. Evaluation of oil palm biomass potential for bio-oil production via pyrolysis processes. International Journal of Integrated Engineering 11(10): 45-52.

$\mathrm{Ku}, \mathrm{X}$., Jin, H. \& Lin, J. 2017. Comparison of gasification performances between raw and torrefied biomasses in an airblown fluidized-bed gasifier. Chemical Engineering Science 168: 235-249.

Kumar, P., Barrett, D.M., Delwiche, M.J. \& Stroeve, P. 2009. Methods for pretreatment of lignocellulosic biomass for efficient hydrolysis and biofuel production. Industrial and Engineering Chemistry Research 48(8): 3713-3729.

Liang, M., Zhang, K., Lei, P., Wang, B., Shu, C.M. \& Li, B. 2019. Fuel properties and combustion kinetics of hydrochar derived from co-hydrothermal carbonization of tobacco residues and graphene oxide. Biomass Conversion and Biorefinery 10: 189-201.

Li, C. \& Suzuki, K. 2009. Tar property, analysis, reforming mechanism and model for biomass gasification-an overview. Renewable and Sustainable Energy Reviews 13(3): 594-604.
Li, F., Xu, M., Wang, T., Fang, Y. \& Ma, M. 2015. An investigation on the fusibility characteristics of low-rank coals and biomass mixtures. Fuel 158: 884-890.

Lopez, G., Artetxe, M., Amutio, M., Alvarez, J., Bilbao, J. \& Olazar, M. 2018. Recent advances in the gasification of waste plastics. A critical overview. Renewable and Sustainable Energy Reviews 82: 576-596.

Mckendry, P. 2002a. Energy production from biomass (part 2): Conversion technologies. Bioresource Technology 83(1): 47-54.

McKendry, P. 2002b. Energy production from biomass (part 3): Gasification technologies. Bioresource Technology 83(1): 55-63.

Milne, T.A., Abatzoglou, N. \& Evans, R. 1998. Biomass Gasifier "tars": Their Nature, Formation, and Conversion, Colorado (US). https://www.nrel.gov/docs/fy99osti/25357. pdf. Accessed on 4 March 2020.

Mishra, R.K. \& Mohanty, K. 2018. Pyrolysis kinetics and thermal behavior of waste sawdust biomass using thermogravimetric analysis. Bioresource Technology 251: 63-74.

Molino, A., Chianese, S. \& Musmarra, D. 2016. Biomass gasification technology: The state of the art overview. Journal of Energy Chemistry 25(1): 10-25.

Monir, M.U., Khatun, F., Abd Aziz, A. \& Vo, D.V.N. 2020. Thermal treatment of tar generated during co-gasification of coconut shell and charcoal. Journal of Cleaner Production 256: 120305

Müller-Langer, F. \& Kaltschmitt, M. 2015. Biofuels from lignocellulosic biomass - a multi-criteria approach for comparing overall concepts. Biomass Conversion and Biorefinery 5: 43-61.

Nakamura, S., Siriwat, U., Yoshikawa, K. \& Kitano, S. 2015. Development of tar removal technologies for biomass gasification using the by-products. Energy Procedia 75: 208-213.

Nakamura, S., Kitano, S. \& Yoshikawa, K. 2016. Biomass gasification process with the tar removal technologies utilizing bio-oil scrubber and char bed. Applied Energy 170: 186-192.

Nanda, S., Mohammad, J., Reddy, S.N., Kozinski, J.A. \& Dalai, A.K. 2014. Pathways of lignocellulosic biomass conversion to renewable fuels. Biomass Conversion and Biorefinery 4(2): 157-191.

Nunalapati, D., Gupta, R., Moghtaderi, B. \& Wall, T.F. 2007. Assessing slagging and fouling during biomass combustion: A thermodynamic approach allowing for alkali/ash reactions. Fuel Processing Technology 88(11-12): 1044-1052.

Nunes, L.J.R., Matias, J.C.O. \& Catalão, J.P.S. 2016. Biomass combustion systems: A review on the physical and chemical properties of the ashes. Renewable and Sustainable Energy Reviews 53: 235-242.

Office of Agricultural Economics. 2018. Agricultural Statistics of Thailand in 2018. Office of Agricultural Economics, Ministry of Agriculture and Cooperatives of Thailand. http://www. oae.go.th/assets/portals/1/ebookcategory/27 yearbook2561/. Accessed on 20 June 2019.

Paethanom, A., Nakahara, S., Kobayashi, M., Prawisudha, P. \& Yoshikawa, K. 2012. Performance of tar removal by absorption and adsorption for biomass gasification. Fuel Processing Technology 104: 144-154.

Paethanom, A., Bartocci, P., Alessandro, B.D., Amico, M.D., Testarmata, F., Moriconi, N., Slopiecka, K., Yoshikawa, K. \& Fantozzi, F. 2013. A low-cost pyrogas cleaning system for 
power generation: Scaling up from lab to pilot. Apply Energy 111: $1080-1088$

Palamanit, A., Khongphakdi, P., Tirawanichakul, Y. \& Phusunti, N. 2019. Investigation of yields and qualities of pyrolysis products obtained from oil palm biomass using an agitated bed pyrolysis reactor. Biofuel Research Journal 24: 10651079.

Pereira, E.G., da Silva, J.N., de Oliveira, J.L. \& Machado, C.S. 2012. Sustainable energy: A review of gasification technologies. Renewable and Sustainable Energy Reviews 16(7): 4753-4762.

Phuphuakrat, T., Namioka, T. \& Yoshikawa, K. 2011. Absorptive removal of biomass tar using water and oily materials. Bioresource Technology 102(2): 543-549.

Plante, L., Sheehan, N.P., Bier, P., Murray, K., Quell, K., Ouellette, C. \& Martinez, E. 2019. Bioenergy from biofuel residues and waste. Water Environment Federation 91(10): 1199-1204

Plis, P. \& Wilk, R.K. 2011. Theoretical and experimental investigation of biomass gasification process in a fixed bed gasifier. Energy 36(6): 3838-3845.

Rajendran, K., Drielak, E., Varma, V.S., Muthusamy, S. \& Kumar, G. 2017. Updates on the pretreatment of lignocellulosic feedstocks for bioenergy production - A review. Biomass Conversion and Biorefinery 8(2): 471-483.

Rasmussen, N.B.K. \& Aryal, N. 2020. Syngas production using straw pellet gasification in fluidized bed allothermal reactor under different temperature conditions. Fuel 263: 116706.

Rubber Authority of Thailand. 2018. Academic Information of Rubber in 2018. https://km.raot.co.th/book/read-product/230. Accessed on 20 June 2019

Saad, M.J., Chia, C.H., Zakaria, S., Sajab, M.S., Misran, S., Rahman, M.H.A. \& Chin, S.X. 2019. Physical and chemical properties of the rice straw activated carbon produced from carbonization and koh activation processes. Sains Malaysiana 48(2): 385-391.

Schuster, G.L., Loffler, G., Weigl, K. \& Hofbauer, H. 2001. Biomass steam gasification - An extensive parametric modeling study. Bioresource Technology 77(1): 71-79.

Seggiani, M., Vitolo, S., Puccini, M. \& Bellini, A. 2012. Cogasification of sewage sludge in an updraft gasifier. Fuel 93: 486-491

Shen, Y. \& Yoshikawa, K. 2013. Recent progresses in catalytic tar elimination during biomass gasification or pyrolysis-a review. Renewable and Sustainable Energy Reviews 21: 371-392.

Shrivastava, P., Khongphakdi, P., Palamanit, A., Kumar, A. \& Tekasakul, P. 2020. Investigation of physicochemical properties of oil palm biomass for evaluating potential of biofuels production via pyrolysis processes. Biomass Conversion and Biorefinery. https://doi.org/10.1007/s13399019-00596-x.

Sikarwar, V.S., Zhao, M., Fennell, P.S., Shah, N. \& Anthony, E.J. 2017. Progress in biofuel production from gasification. Progress in Energy and Combustion Science 61: 189-248.

Stevens, D.J. 2001. Hot gas conditioning: Recent progress with larger-scale biomass gasification systems. National Renewable Energy Laboratory. https://www.nrel.gov/docs/ fy01osti/29952.pdf.

Susastriawan, A.A.P., Saptoadi, H. \& Purnomo. 2017. Smallscale downdraft gasifiers for biomass gasification: A review. Renewable and Sustainable Energy Reviews 76: 989-1003.
Tanger, P., Field, J.L., Jahn, C.E., Defoort, M.W. \& Leach, J.E. 2013. Biomass for thermochemical conversion: Targets and challenges. Frontiers in Plant Science 4: 1-20.

Tarnpradab, T., Unyaphan, S., Takahashi, F. \& Yoshikawa, K. 2016. Tar removal capacity of waste cooking oil absorption and waste char adsorption for rice husk gasification. Biofuels 7(4): 401-412.

Thapa, S., Bhoi, P.R., Kumar, A. \& Huhnke, R.L. 2017. Effects of syngas cooling and biomass filter medium on tar removal. Energies 10(3): 349.

Tursi, A. 2019. A review on biomass: Importance, chemistry, classification, and conversion. Biofuel Research Journal 6(2): 962-979.

Unyaphan, S., Tarnpradab, T., Takahashi, F. \& Yoshikawa, K. 2017. An investigation of low cost and effective tar removal techniques by venturi scrubber producing syngas microbubbles and absorbent regeneration for biomass gasification. Energy Procedia 105: 406-412.

Valderrama Rios, M.L., González, A.M., Lora, E.E.S. \& Almazán del Olmo, O.A. 2018. Reduction of tar generated during biomass gasification: A review. Biomass and Bioenergy 108: 345-370.

Vecchione, L., Cossio, F. \& Longo, L. 2016. Comparison of different systems for tar removal for renewable energy derivation from biomass gasification. Contemporary Engineering Sciences 9(9): 413-423.

Watson, J., Zhang, Y., Si, B., Chen, W.T. \& de Souza, R. 2018. Gasification of biowaste: A critical review and outlooks. Renewable and Sustainable Energy Reviews 83: 1-17.

Werther, J., Saenger, M., Hartge, E.U., Ogada, T. \& Siagi, Z. 2000 Combustion of agricultural residues. Progress in Energy and Combustion Science 26(1): 1-27.

Widjaya, E.R., Chen, G., Bowtell, L. \& Hills, C. 2018 Gasification of non-woody biomass: A literature review. Renewable and Sustainable Energy Reviews 89: 184-193.

Yao, X., Zhou, H., Xu, K., Xu, Q. \& Li, L. 2020. Investigation on the fusion characterization and melting kinetics of ashes from co-firing of anthracite and pine sawdust. Renewable Energy 145: 835-846.

Yokoyama, S.Y., Ogi, T. \& Nalampoon, A. 2000. Biomass energy potential in Thailand. Biomass and Bioenergy 18(5): 405-410.

Yu, L.Y., Wang, L.W. \& Li, P.S. 2014. Study on prediction models of biomass ash softening temperature based on ash composition. Journal of the Energy Institute 87(3): 215-219.

Zhu, Y., Niu, Y., Tan, H. \& Wang, X. 2014. Short review on the origin and countermeasure of biomass slagging in grate furnace. Frontiers in Energy Research: Bioenergy and Biofuel 2(7): 1-10.

Syed Haseeb Sultan

Sustainable Energy Management Program

Faculty of Environmental Management

Prince of Songkla University

Hat Yai, Songkhla 90110

Thailand

Arkom Palamanit*

Interdisciplinary Graduate School of Energy Systems

Prince of Songkla University

Hat Yai, Songkhla 90110

Thailand 
Kua-anan Techato

Environmental Assessment and Technology for Hazardous Waste

Management Research Center

Faculty of Environmental Management

Prince of Songkla University

Hat Yai, Songkhla 90110

Thailand

Muhammad Amin \& Asadullah

Department of Chemical Engineering

Faculty of Engineering

BUITEMS, Quetta

Pakistan
Khurshid Ahmed

Molecular Biotechnology Laboratory

Department of Industrial Biotechnology

Faculty of Agro-Industry

Prince of Songkla University

Songkhla province

Thailand

*Corresponding author; email: arkom.p@psu.ac.th

Received: 6 October 2019

Accepted: 12 March 2020 

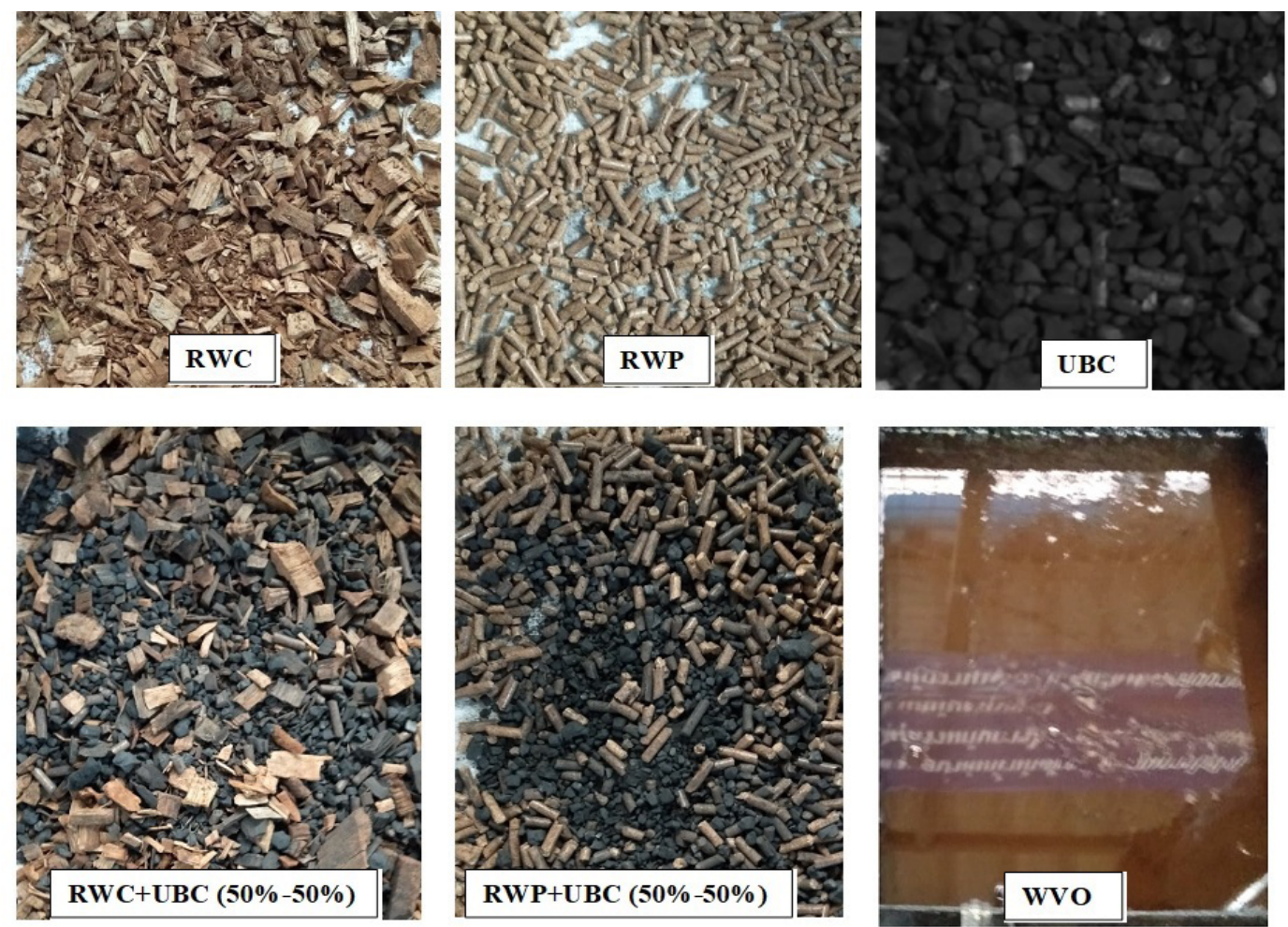

FIGURE S1. Biomass feedstocks for gasification and WVO for scrubbing to remove tar
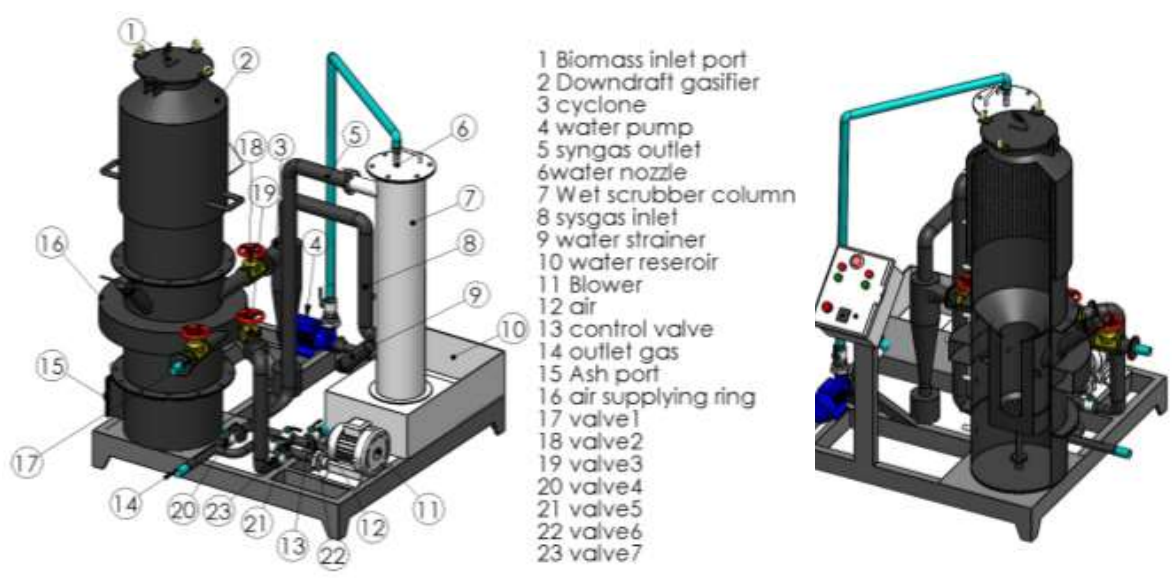

(a) Downdraft gasifier
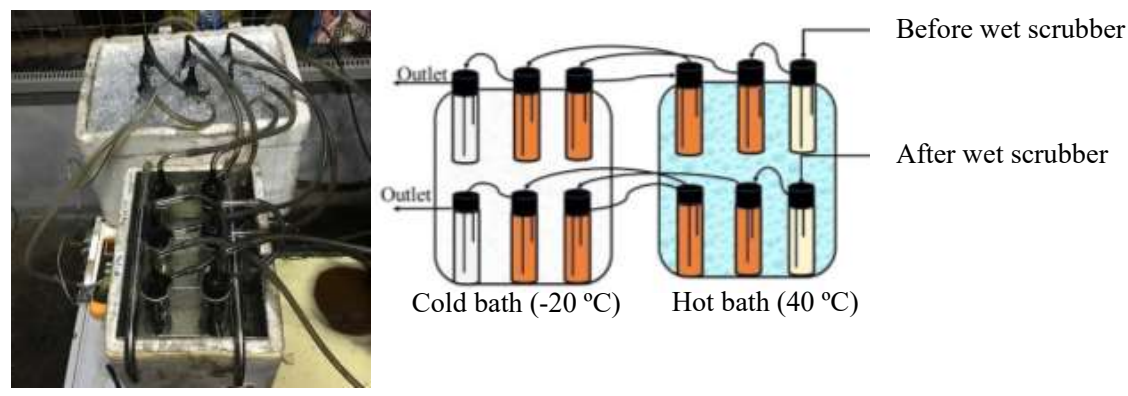

(b) Tar sampling train system

FIGURE S2. Schematic diagram of gasifier and tar removal system used in this study 